\begin{tabular}{|c|c|c|}
\hline \multicolumn{3}{|c|}{ Jurnal Warna : Jurnal Pendidikan Dan Pembelajaran Anak Usia dini. } \\
Maret 2020. Vol 05. No. 01 \\
\hline Received: Maret 2020 & Accepted: Maret 2020 & Published: Maret 2020 \\
\hline & Article DOI: $10.24903 /$ jw.v5i1.429 \\
\hline
\end{tabular}

\title{
PENGARUH MEDIA PLAYDOUGH TERHADAP PERKEMBANGANKOGNITIF ANAK USIA 5 - 6 TAHUN DI TK WIDYA KUMARA SANTHI KECAMATAN BANJAR KABUPATEN BULELENG
}

\author{
I Made Hartawan \\ STAH N MPU Kuturan Singaraja \\ hartawanmade51@gmail.com
}

\begin{abstract}
Abstrak
Tujuan dari penelitian ini adalah untuk mengetahui apakah ada pengaruh media bermain terhadap perkembangan kognitif anak usia 5-6 tahun di TK Widya Kumara Santhi, Kecamatan Banjar, Kabupaten Buleleng, Tahun Akademik 2016/2017. Playdough adalah salah satu aktivitas yang bermanfaat untuk perkembangan otak anak. Perkembangan kognitif adalah perubahan dalam pemikiran atau kemampuan intelektual. Menurut Peraturan Menteri Pendidikan no. 58 tahun 2009 mengungkapkan bahwa salah satu aspek perkembangan kognitif yang perlu dikembangkan pada anak usia 5-6 tahun adalah konsep bentuk, warna, ukuran, dan pola. Bentuk yang diajarkan kepada anak-anak adalah bentuk geometris seperti lingkaran, segitiga, kotak, dan persegi panjang. Jenis penelitian ini menggunakan pendekatan kuantitatif, target penelitian ini adalah 30 anak usia 5-6 tahun di TK Widya Kumara Santhi, Kecamatan Banjar, Kabupaten Buleleng. Dari hasil penelitian kuantitatif menggunakan Pre Experiments dengan tipe satu kelompok pre-test dan post-test desaign. Berdasarkan hasil uji t, nilai signifikansi (sig) adalah 0,000. Nilai signifikansi uji t lebih kecil dari batas maksimum yang ditetapkan pada $0,05(\mathrm{sig} \geq 0,05)$ sehingga dapat disimpulkan jika ada perbedaan yang signifikan dalam perkembangan kognitif anak sebelum dan sesudah menggunakan media play. Dari hasil paired sample t test, dapat disimpulkan bahwa media play memiliki efek pada perkembangan kognitif (Ha diterima). Dengan diterimanya hipotesis kerja maka dapat disimpulkan bahwa media playdough memiliki pengaruh yang cukup tinggi terhadap Perkembangan Kognitif Anak Usia 5-6 Tahun di TK Widya Kumara Santhi, Kecamatan Banjar, Kabupaten Buleleng.
\end{abstract}

Kata kunci: Media Playdough, Pengembangan Kognitif

\begin{abstract}
The purpose of this research is to find out whether there is an influence of media play on the cognitive development of children aged 5-6 years at Widya Kumara Santhi Kindergarten, Banjar District, Buleleng Regency 2016/2017 Academic Year. Playdough is one activity that is beneficial for the development of a child's brain. Cognitive development is a change in thinking or intellectual abilities. According to Minister of Education Regulation no. 58 of 2009 revealed that one aspect of cognitive development that needs to be developed in children aged 5-6 years is the concept of shape, color, size, and pattern. Shapes taught to young children are geometric shapes such as circles, triangles, squares and rectangles. This type of research is using a quantitative approach, the target of this study is 30 children aged 5-6 years at TK Widya Kumara Santhi, Banjar District, Buleleng Regency. From the results of quantitative research using Pre Experiments with the type of one group pre-test and post-test desaign. Based on the results of the $t$ test, the significance value ( $\mathrm{sig}$ ) was 0,000 . The significance value of the $t$ test is smaller than the maximum limit set at 0.05 ( $\mathrm{sig} \geq 0.05$ ) so that it can be concluded if there are significant differences in the cognitive development of children before and after using media play. From the results of the paired sample t test, it can be concluded that media play has an effect on cognitive development (Ha accepted). With the acceptance of the working hypothesis it can be concluded that the media playdough has a quite high influence on the Cognitive Development of Children Aged 5-6 Years at Widya Kumara Santhi Kindergarten, Banjar District, Buleleng Regency.
\end{abstract}

Keywords: Playdough Media, Cognitive Development 


\begin{tabular}{|c|c|c|}
\hline \multicolumn{3}{|c|}{ Jurnal Warna : Jurnal Pendidikan Dan Pembelajaran Anak Usia dini. } \\
& Maret 2020. Vol 05. No. 01 \\
\hline Received: Maret 2020 & Accepted: Maret 2020 & Published: Maret 2020 \\
\hline & Article DOI: $10.24903 /$ jw.v5i1.429 \\
\hline
\end{tabular}

\section{PENDAHULUAN}

Proses perkembangan manusia secara utuh dimulai sejak janin dalam kandungan ibunya dan memasuki usia emas (golden age) sampai usia 6 tahun. Usia 0-6 tahun, merupakan masa peka bagi anak sehingga para ahli menyebutnya the golden age, karena perkembangan kecerdasanya mengalami peningkatan yang signifikan. Usia dini atau prasekolah merupakan kesempatan emas bagi anak untuk belajar,oleh karena itu, kesempatan ini hendaknya dimanfaatkan sebaik-baiknya untuk pembelajaran anak karena rasa ingin tau anak usia dini ini berada pada posisi puncak. Tidak ada usia sesudahnya yang menyimpan rasa ingin tau anak melebihi usia dini.

Berdasarkan permendikbud No.137 tahun 2014 (SN PAUD) diantaranya adalah standar tingkat pencapaian perkembangan anak usia dini disebut STPPA adalah kriteria tentang kemampuan yang di capai anak pada seluruh aspek perkembangan dan pertumbuhan mencakup aspek nilai agama dan moral ,fisik motorik, kognitif, bahasa, sosial emosional serta seni. Standar PAUD berfungsi sebagai dasar dalam perencanaan, pelaksanaan, pengawasan dan tindak lanjut pendidikan dalam rangka mewujudkan tujuan pendidikan nasional dan dasar penjaminan mutu PAUD. Standar tingkat PAUD bertujuan untuk melakukan stimulasi pendidikan dalam membantu pertumbuhan dan perkembangan jasmani dan rohani sesuai dengan tingkat pencapaian perkembangan anak.
Dalam Undang-Undang No. 20 Tahun 2003 pasal 13 ayat 1 dikemukakan sebagai berikut: Jalur pendidikan terdiri atas Pendidikan Formal, Non Formal dan Informal yang dapat saling melengkapi dan memperkaya. Pendidikan Informal dan Non Formal merupakan pendidikan yang berlangsung diluar sekolah yang bertujuan untuk memenuh kebutuhan belajar rmasyarakat yang tidak dapat dipenuhi dalam Pendidikan Formal. Anak adalah manusia kecil yang memiliki potensi yang masih harus dikembangkan.

Anak memiliki karakteristik tertentu yang khas dan tidak sama dengan orang dewasa, mereka selalu aktif, dinamis, antusias dan ingin tahu. Selanjutnya dalam UU No 20 Tahun 2003 tentang Sistem Pendidikan Nasional bab 1 pasal 1 butir 14 dikemukakan bahwa; Pendidikan sudah dimulai sejak usia dini yaitu suatu upaya pembinaan yang ditujukan kepada anak sejak lahir sampai dengan usia enam tahun yang dilakukan melalui pemberian rangsangan pendidikan untuk membantu pertumbuhan dan perkembangan jasmani dan rohani agar anak memiliki kesiapan dalam memasuki pendidikan lebih lanjut.

Menurut Anggraini menyatakan sebagai berikut : Permainan playdough adalah salah satu aktifitas yang bermanfaat untuk perkembangan otak anak. Dengan bermain playdough, anak tak hanya memperoleh kesenangan, tapi juga bermanfaat untuk meningkatkan 


\begin{tabular}{|c|c|c|}
\hline \multicolumn{3}{|c|}{ Jurnal Warna : Jurnal Pendidikan Dan Pembelajaran Anak Usia dini. } \\
& Maret 2020. Vol 05. No. 01 \\
\hline Received: Maret 2020 & Accepted: Maret 2020 & Published: Maret 2020 \\
\hline & Article DOI: $10.24903 /$ jw.v5i1.429 \\
\hline
\end{tabular}

perkembangan otaknya. Dengan media playdough anak bisa menciptakan berbagai bentuk seperti buah, sayur, alat transportasi dan media-media yang lain yang bisa diajarkan guru kepada anak didik dalam pembelajaran. Bermain dengan media Playdough dapat memberikan penglaman secara langsung kepada anak, dimana anak langsung membentuk sendiri media playdough menjadi bentuk-bentuk yang anak sukai. Pestalozzi (dalam Badru 2009: 1.6) berkeyakinan, bahwa "segala bentuk pendidikan adalah berdasarkan pengaruh panca indra, dan melalui pengalamanpengalaman tersebut potensi-potensi yang dimiliki oleh seorang individu dapat dikembangkan". Cara belajar yang terbaik untuk mengenal berbagai konsep adalah dengan melalui berbagai pengalaman, antara lain dengan merasakan dan menyentuhnya. Sedangkan menurut Immanuella F. R, dkk menjelaskan bahwa berkreasi dengan media playdough merupakan kegiatan paling populer dan dapat mencerdaskan anak. Selain mengasah imajinasi, kemapuan motorik halus, berfikir logis dan sistematis, juga merangsang indera perabanya.

Perkembangan kognitif merupakan perkembangan yang menun jukan cara berfikir anak dalam menyelesaikan berbagai masalah (patmonodewo, 2003:27). Perkembangan kognitf ini perlu di kembangkan sejak usia dini, karena memiliki dampak besar bagi kehidupan anak di masa mendatang. Menurut permendiknas no.58 tahun 2009 mengungkapkan bahwa salah satu aspek perkembangan kognitif yang perlu di kembangkan pada anak usia 5-6 tahun adalah konsep bentuk, warna, ukuran, dan pola. Bentuk-bentuk yang di ajarkan pada anak usia dini adalah bentuk-bentuk geometri seperti lingkaran, segitiga,persegi, dan persegi panjang. Pendapat Beaty (2013:281) yang mengemukakan bahwa bayi usia 4-6 bulan mampu untuk membedakan warna. Hal ini berarti, sejak usia 4-6 bulan anak mampu mengenal warna.,

Berdasarkan uraian di atas media playdough dan perkembangn kognitif saling berkaitan yaitu cara bermain dalam playdough ini dengan mengerakan jarijari,menekan,meraba dan berfikir hingga menjadi bentuk yang diingnkan proses menggerakan jari dan berfikir anak dapat merangsang saraf morotik anak, saraf motorik tersebut yang menghubungkan ke otak sehingga terjadi perkembangan kognisi di otak semakin besar gerakan jari semakin besar pola saraf motorik yang bergerak di dalam otak. Berdasarkan hal tersebut peneliti mengunakan permasalahan di atas sebagai penenelitian dengan judul "Pengaruh Media playdough Terhadap Perkembangan Kognitif Anak Usia 5-6 Tahun Di TK Widya Kumara Santhi Kecamatan Banjar Kabupaten Buleleng”

\section{METODE}

Rancangan penelitian sering disebut dengan kerangka kerja yang merupakan bagian dari suatu kegiatan penelitian, tujuannya yaitu 


\begin{tabular}{|c|c|c|}
\hline \multicolumn{3}{|c|}{ Jurnal Warna : Jurnal Pendidikan Dan Pembelajaran Anak Usia dini. } \\
& Maret 2020. Vol 05. No. 01 \\
\hline Received: Maret 2020 & Accepted: Maret 2020 & Published: Maret 2020 \\
\hline & Article DOI: $10.24903 /$ jw.v5i1.429 \\
\hline
\end{tabular}

untuk memudahkan kegiatan dalam penelitian sehingga dapat mempermudah pemecahan masalah, sehingga mendapat data yang valid dan sesuai dengan tujuan penelitian. Pada penelitian ini peneliti menggunakan rancangan pendekatan kuantitatif dengan jenis penelitian menggunakan pre Eksperimen dengan tipe one group pre-test dan post- test, yaitu desain ini dilakukan pre test sebelum diberi perlakuan .dengan demikian hasil perlakuan dapat diketahui lebih akurat karena dapat membandingkan dengan keadaan sebelum diberi perlakuan. (sugiono: 2015).

Setelah pengumpulan data dilakukan maka langkah selanjutnya aamenganalisis data tersebut dengan menggunakan metode-metode tertentu untuk dapat menjawab masalah penelitian serta dapat menguji hipotesis yang telah dirumuskan. Koentjaraningrat (1991) mengemukakan bahwa " Analisis kuantitatif adalah data yang di kumpulkan berjumlah kecil, bersifat monografis atau berwujud kasus-kasus, sehingga tidak dapat disusun kedalam struktur klasifikasi. Analisis kuantitatif adalah data yang dikumpulkan itu berjumlah besar dan mudah diklasifikasikan kedalam suatu kategori-kategori."

Dalam analisis data ini peneliti menggunakan analisis kuantitatif disebabkan data yang diperoleh bewujud angka-angka. Oleh karena itu analisis data yang digunakan adalah statistik sesuai dengan pendapat Sugiyono (2001) yang menyatakan bahwa “ tehnik analisis data dalam penelitian kuantitatif menggunakan statistik".
Berdasarkan teori-teori diatas maka penulis menggunakan analisis data kuantitatif atau statistik yaitu suatu jenis metode yang mengukur secara langsung atau lebih tepatnya menghitung data. Untuk mengolah data hasil uji coba perorangan, uji coba kelompok kecil, uji coba kelompok besar digunakan teknik data.

\section{HASIL DAN PEMBAHASAN}

Pada bab ini akan dibahas tentang analisis hasil penelitian yang dikaitkan dengan tujuan penelitian sebagaimana yang telah dikemukakan pada bab sebelumnya. Deskripsi data yang disajikan berupa data yang diperoleh dari hasil tes lembar observasi media playdough terhadap perkembangan kognitif anak usia 5-6 tahun di TK Widya Kumara Santhi Kecamatan Banjar Kabupaten Buleleng

Penghitungan data dilakukan dengan program komputer Statistical Program For Social Science (SPSS) for windows evaluations 20.0 yaitu dengan mengunakan uji normalitas yang bertujuan untuk mengetahui data yang di peroleh memenuhi absumsi normal dan uji sampel berpasangan (tpaired)yang bertujuan untuk mengetahui perbedan rata-rata variable dalam satu kelompok. Adapun hasil observasi dan dokumentasi gambaran umum tentang Widya Kumara Santhi Kecamatan Banjar Kabupaten Buleleng. Desain Eksperimen One Group PreTest Dan Post-Test Design (Sugiono,2011:74) $o_{1}$ Adalah nilai hasil perolehan kemampuan perkembangan kognitif pada anak sebelum 


\begin{tabular}{|c|c|c|}
\hline \multicolumn{3}{|c|}{ Jurnal Warna : Jurnal Pendidikan Dan Pembelajaran Anak Usia dini. } \\
Maret 2020. Vol 05. No. 01 \\
\hline Received: Maret 2020 & Accepted: Maret 2020 & Published: Maret 2020 \\
\hline & Article DOI: $10.24903 /$ jw.v5i1.429 \\
\hline
\end{tabular}

menggunakan media playdough, sedangkan $\mathrm{O}_{2}$ adalah nilai hasil perkembangan kognitif pada anak sesudah menggunakan media playdough. Model dikatakan efektif apabila terdapat perbedaan perlakuan dan setelah perlakuan dengan media pembelajaran playdough.

1. Paparaan dari hasil uji coba

a) Uji Coba Perorangan

Uji coba ini dilakukan oleh peneliti kepada 8 anak usia 5-6 tahun dean guru kelasnya .tahap ini bertujuan untuk pengaruh awal kegiatan playdough tersebut

b) Uji coba kelompok kecil

Pada tahap ini pengujian dilakukan pada beberapa anak untuk mendapatkan respon anak dari kegiatan kolase yang dikenalkan. Tahap ini dilakukan oleh peneliti kepada 15 anak usia 5-6 tahun dan guru kelasnya.

2. Uji coba lapangan

Pada tahap ini penguji dilakukan pada uji lapangan dengan menerapkan kegiatan media playdough terhadap perkembangan kognitif anak usia 4-5 tahun.

Tahap uji coba lapangan di lakukan pada observasi pada subjek oleh observer yakni guru kelas. Uji coba lapang ini bertujuan untuk mengetahui pengauh media playdough terhadap perkembangan kognitif anak usia 5-6 tahun. Pada tahap ini juga akan di adakan sebelum dan sesudah perlakuan di awal dan di akhir yahap uji lapanguntuk mengetahui pencapaian perekembangan kognitif anak, peneliti menggunakan Pre Eksperimen dengan tipe one group pre test dan post-test design.

Penilaian observer menunjukan perkembangan kognitif anak kelompok besar pada keadaan sebelum dan sesudah menggunakan media playdough mengalami perubahan. Sebelum menggunakan playdough media yang di gunakan belum menunjukan pengaruh perkembangan kognitif, sesudah menggunakan media playdough tampak mengalami perubahan terhadap perkembangan kognitifnya.

Setelah melakukan uji coba, hasil uji coba yang diperoleh dari pedoman observasi ditabulasi sebagai dasar uji efektifitas kolase daun kering. Tabulasi data diperoleh dari hasil pedoman obseervasi kelompok besar. Sebelum menentukan alat uji efektifitas perlu dilakukan uji beda, sebelum uji beda dilakukan perlu uji normalitas data yang diperoleh.

a. Uji normalitas data

Uji normalitas data merupakan uji yang dilakukan dengan tujuan mengetahui data yang diperoleh memenuhi absumsi normal. Uji normalitas juga dibutuhkan untuk menentukan alat analisis yang dipakai untuk melakukan uji beda perkembangan kognitif.

Sebelum dan sesudah menggunakan media playdough. Hasil uji normalitas data menggunakan software SPSS ver 20.0 for windows disajikan pada table berikut: 


\begin{tabular}{|c|c|c|}
\hline \multicolumn{3}{|c|}{ Jurnal Warna : Jurnal Pendidikan Dan Pembelajaran Anak Usia dini. } \\
Maret 2020. Vol 05. No. 01 \\
\hline Received: Maret 2020 & Accepted: Maret 2020 & Published: Maret 2020 \\
\hline & Article DOI: $10.24903 /$ jw.v5i1.429 \\
\hline
\end{tabular}

\begin{tabular}{|l|r|r|r|}
\hline \multicolumn{4}{|c|}{ One-Sample Kolmogorov-Smirnov Test } \\
\hline N & & Sebelum & Sesudah \\
\hline Normal Parameters a,b & Mean & 30 & 30 \\
& Std. Deviation & 5,50 & 9,10 \\
Most Extreme & Absolute & 1,042 & 1,322 \\
Differences & Positive &, 184 &, 197 \\
& Negative &, 184 &, 197 \\
Kolmogorov-Smirnov Z & &,- 184 &,- 137 \\
Asymp. Sig. (2-tailed) & 1,009 & 1,078 \\
\hline & &, 260 &, 196 \\
\hline a. Test distribution is Normal. & & \\
b. Calculated from data. &
\end{tabular}

Hasil uji normalitas diperoleh nilai zhitung pada pretest sebesar 1,009 dengan signifikansi sebesar 0,260 dan z-hitung pada posttest sebesar 1,078 dengan signifikansi sebesar 0,196. Nilai signifikansi pada pretest $(0,260)$ dan posttest $(0,196)$ masing-masing lebih besar dari $\alpha(0,05)$, sehingga data dalam penelitian ini menyebar menurut distribusi normal.

Karena subjek penelitian berjumlah $\leq 50$, maka nilai signifikasi KolmogorovSmirnov diabaikan, dan yang digunakan sebagai acuan adalah hasil signifikasi ShapiroWilk yaitu sig 0,30 sebelum perlakuan dan sig 0,83 sesudah mendapat perlakuan. Hasil uji normalitas menunjukan bahwa nilai signifikasi lebih besar dari batas minimum yang ditentukan yaitu sig $\geq 0,05$ : artinya data yang diperoleh berdistribusi normal.

Karena hasil uji normalitas data sebelum dan sesudah menggunakan kolase daun kering berdistribusi normal, maka alat analisis yang digunakan untuk menguji perbedaan kemampuan motorik halus anak sebelum dan sesudah menggunakan kolase daun kering adalah uji sampel t berpasangan.

b. Uji sampel berpasangan (t-paired)
Uji t sampel berpasangan merupakan uji statistik yang digunakan untuk menguji perbedaan rata-rata variable dalam satu kelompok. Uji t sampel berpasangan dilakukan apabila data yang digunakan memenuhi asumsi normalitas. Hasil uji $t$ sampel berpasangan menggunakan SPSS ve20.0 for windows yang disajikan pada table berikut:

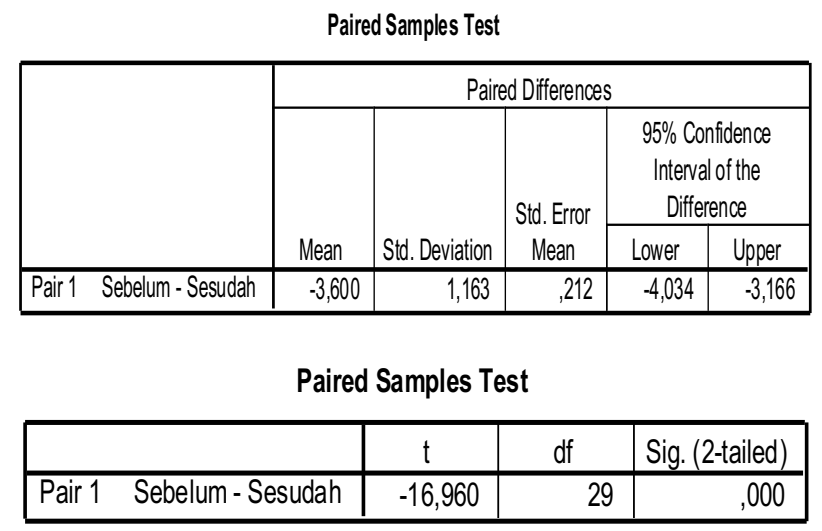

Sumber data lampiran 8

Hasil perhitungan dengan uji t sampel berpasangan diperoleh nilai t-hitung sebesar 16,960 dengan signifikansi sebesar 0,000. Nilai signifikansi sebesar 0,000 lebih kecil dari $\alpha(0,05)$, sehingga dapat dinyatakan bahwa terdapat pengaruh (perbedaan) penggunaan media playdough terhadap perkembangan kognitif anak usia 5-6 tahun. Nilai negatif dalam t-hitung menunjukkan terdapat peningkatan perkembangan kognitif antara sebelum dan sesudah perlakuan.

\section{PENUTUP}

\section{Kesimpulan}

Di hasil uraian di atas dapat di simpulkan bahwa playdough memiliki manfaat dan pengaruh yang sangat penting bagi perkembangan kognitif anak, dengan 


\begin{tabular}{|c|c|c|}
\hline \multicolumn{3}{|c|}{ Jurnal Warna : Jurnal Pendidikan Dan Pembelajaran Anak Usia dini. } \\
& Maret 2020. Vol 05. No. 01 \\
\hline Received: Maret 2020 & Accepted: Maret 2020 & Published: Maret 2020 \\
\hline & Article DOI: $10.24903 /$ jw.v5i1.429 \\
\hline
\end{tabular}

menggunakan playdough anak dapat menggunakan secara langsung melalui panca indra dan pengalamanya dengan merasakan dan mentuhnya,metode kuantitatif dan jenis penelitian pre Eksperimen dengan tipe posttest dan pre-test yang di gunakan peneliti yang menunjuk langsung Tk Widya Kumara Santhi Kecamatan Banjar Kabupaten Buleleng sebagai penetuan daerah penelitian dengan responden 30 anak yang menggunakan teknik analisis data uji perorangan, kelompok kecil dan kelompok besar yang kemudian hasil datanya di olah di SPSS ver20.0 for windows dengan rumus t paired sehingga mendapatkan hasil perhitungan dengan uji $t$ sampel berpasangan diperoleh nilai t-hitung sebesar 16,960 dengan signifikansi sebesar 0,000. Nilai signifikansi sebesar 0,000 lebih kecil dari $\alpha(0,05)$, yang dapat di artikan bahwa media playdough memiliki pengaruh yang sangat signifikan terhadap perkembanngan kognitif anak usia 5-6 tahun di TK Widya Kumara Santhi Kecamatan Banjar Kabupaten Buleleng.

\section{Saran}

Setelah melihat uraian tersebut nampak bahwa media playdough mempunyai pengaruh yang cukup tinggi dalam mengembangkan perkembangan kognitif anak usia 5-6 tahun di TK Widya Kumara Santhi Kecamatan Banjar Kabupaten Buleleng. Oleh karena itu, sebagai bahan pertimbangan penulis memberikan saran-saran sebagai berikut:
1. Seorang guru harus dapat memilih metode dan lebih kreatif dalam memncoba ide baru agar proses pembelajaran berhasil dengan baik dan tidak membosankan.

2. Hendaknya guru selalu memotivasi siswa untuk selalu belajar dirumah, materi yang akan dibahas pada pertemuan berikutnya supaya dalam pembelajaran siswa mempunyai gambaran materi.

3. Bagi sekolah, Perlu memperhatikan untuk pengadaan alat permainan yang mendidik secara memadai karena mengingat pentingnya alat tersebut bagi anak-anak

4. Media Playdough diharapkan dapat dijadikan kegiatan untuk melatih perkembangan kognitif anak.

\section{DAFTAR PUSTAKA}

Haryani. C. (2014). Penerapan Media Bermain Dengan Media Playdough Dalam Meningkatkan Kemampuan Mengenal Konsep Bilangan. Penelitian Tindakan Kelas , 42-45.

Haryani.C.(2014).Pengaruh Metode Bermain Dengan Media Playdough Dalam Meningkatkan Kemampuan Mengenal Konsep Bilangan. Kota Bengkulu

Hartati.sofia.(2005).Perkembangan Belajar Anak Usia Dini. Jakarta: Depdiknas.

Hurlock.B.Elizabeth.(1978).PerkembanganAnak.

(Terjemahan: Med MeitasariTjandrasa Dan MuchicahZarkasih).

Isriyah. M. (2015). Pengenalan Konsep Uang Untuk Anak Taman Kanak - Kanak. Prosiding Seminar Nasional PAUD. 154-155.

Ilum.MualifahDkk.(2008).PerkembanganPesetraD idik. Surabaya: Lapis PGMI. 


\begin{tabular}{|c|c|c|}
\hline \multicolumn{3}{|c|}{ Jurnal Warna : Jurnal Pendidikan Dan Pembelajaran Anak Usia dini. } \\
Maret 2020. Vol 05. No. 01 \\
\hline Received: Maret 2020 & Accepted: Maret 2020 & Published: Maret 2020 \\
\hline & Article DOI: $10.24903 /$ jw.v5i1.429 \\
\hline
\end{tabular}

Kasmini. (2012). Pemanfaatan Media Playdough Untuk Meningkatkan Kreatifitas Pada Anak Kelompok B Di TK Kurnia Simo Tambaan Surabaya. Penelitian Tindakan Kelas , 3-5.

Kasmini.(2012:38) Pemanfaatan Media Playdough Untuk Meningkatkan Kreatifitas Pada Anak Kelompok B Di TK Kurnia Simo Tamban. Surabaya.

Mj. U. (2012). Teori Perkembangan Kognitif Dalam Proses Belajar mengajar. Jurnal edukasi Vo.7, 2-10.

Moestiehatoen. (2004).Metode Pengajaran TK. Semarang: Rineka Cipta

Tadzkitotun.Musfiroh.(2005).BerceritaUntukAnak Usia Dini. Jakarta Utama.

Sumiharsono.Rudy.(1990).Pedoman Penulisan Karya Ilmiah.Jember:IKIPPGRI.

Siregar.syofian.(2013). Metode Penelitian

Kuantitatif: Dilengkapi Dengan Perhitungan

Manual Dan SPSS. jakarta: KENCANA

Prenada Media Group.

Suyanto.Slamet.(2005).Konsep Dasar Pendidikan Anak Usia Dini. Jakarta: Depdiknas

Smith,E.dkk. (2014). Psikologi Kognitif.

Yokyakarta:Pustaka Belaja..

Sugiono.(2015) .MetodelogiPenelitian Pendidikan.

Bandung. Alfabeta.cv.

Hartono.Sunarto.(2008).Perkembangan Peserta

Didik, Jakarta:PT.Rineka Cipta.

Tatik.Diyu.(2013:43.) Peningkatan Kemampuan

Motorik Halus Melalui Media Playdough Anak Kelompok A Di Tk Dewi Kunti. Surabaya.

Tatik. D. (2015). Meningkatkan Kemampuan

Motorik Halus Melalui Media Playdough.

Penelitian Tindakan Kelas , 4.

Wahyuni. Nani (2010). Definisi Perkembangan.

Retrieved

from http:/edukasi.kompasiana.com/2010/10/25/de finisi-perkembangan/ on 10 January 2013. 